\title{
Journal of Educational Sciences
}

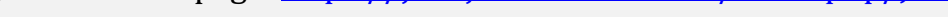

\section{Growth of Care Characters in the Lisambil Discussion of Student in Smp Negeri 21 Pekanbaru}

\author{
Deswati $^{1,2}$, Suwondo ${ }^{1}$, Firdaus LN ${ }^{1}$ \\ ${ }^{\text {I}}$ SMP Negeri 21 Pekanbaru, Riau, Indonesia \\ ${ }^{2}$ Biology Education, Postgraduate, University of Riau, Pekanbaru, Indonesia
}

\section{ARTICLE INFO}

\section{Article history:}

Received: 25 June 2019

Revised: 27 Sept 2019

Accepted: 04 Jan 2020

Published online: 24 Jan 2020

\section{Keywords:}

Environmental Concern Character

Lisambil

Habituation

\begin{abstract}
A B S T R A C T
The character of caring for students environment is still low. The study aims to evaluate the growth of environmental care character of students, at SMP Negeri 21 Pekanbaru. The parameters of research were the perception of teachers, principals, students and the growth of environmentally conscious character aspects of the action of growing brothers caring for the environment and environmental cleanliness after the action. The results of the study shows the teacher perceptions with average of $4.44(88 \%)$ in the good category. The school principals is $4.69(94 \%)$ in the good category and student score is 4.24 $(79 \%)$ in the good category. Students perception of habituation aspects before KBM averaged a score of 1.90 $(63 \%)$ enough category. The act of growing character cares for the environment with an average of $69 \%$ (good), in the aspect of implementation of the class picket the average is $56 \%$ (enough). Environmental hygiene in the class average of $77 \%$ (good), in terms of cleaning activities before KBM averaged 60\% (enough). Environmental cleanliness with an average of $28.7 \%$ (less). The growth of students environmental care character from caring actions is showing in the good category and environmental cleanliness in the classroom category is sufficient and outside the classroom category is lacking.
\end{abstract}

\section{Introduction}

National education functions to develop and shape the dignity and character of a nation that is dignified in the intellectual life of the nation with the aim of developing the potential of students to become people of faith and devotion to a God who is almighty. Education is a process of cultural inheritance and national

\footnotetext{
${ }^{*}$ Corresponding author. Tel./Fax.: +6285274124842

E-mail: deswati.riau@gmail.com
} 
character for young people to improve the quality of life of the nation in the future (Ministry of National Education, 2010). Therefore education is believed by everyone as a forum to prepare exceptional human character, this is believed because with the character of Indonesia will be a strong nation in facing global challenges in all sectors in 2045. Schools become agents of change in shaping attitudes, behaviors towards character which characterizes the basic values of the nation's character (Rokhman et al., 2013). Character education in schools is integrated in learning. Integrating character education is expected to be a tool and opportunity for students to develop various good characters (Agung, 2011). According to Sofian (2018), the process of internalizing character education is carried out through four methods: socialization, teaching and learning, habituation and role models. According to Irene \& Dwiningrum (2013), character education will succeed optimally if supported by social capital, schools have social capital, such as student participation activities in schools in solving environmental problems, social capital as a collective force to strengthen student character. This is in line with the opinion of Bandura et.al, (2006), habituation of part of social learning that is formed from direct experience through observation of others, through models of action, symbols, and values and behavior that occur.

Character care for the environment is the attitude and action towards the environment by preventing the occurrence of environmental damage and striving to repair the damaged environment (Malik et al., 2015) Character education is a system of inculcating character values to school residents which includes components of knowledge, awareness or willingness, and actions to implement these values (Zainal \& Sujak, 2011). According to Chusaini (2013), efforts are planned and carried out systematically to assist students in understanding human values and behavior related to God, self, fellow individuals, the environment that is manifested in thoughts, feelings, words, attitudes and actions that in accordance with religious, legal, ethical, cultural and customary norms.

An unresolved environmental problem is environmental pollution caused by garbage. The results of the national socioeconomic survey on indicators of environmental care behavior towards waste behavior obtained data that actions to litter, such as sewers, rivers and the sea are still at $21.64 \%$ in rural and urban areas, while for waste management by not sorting out waste organic and inorganic at $81.04 \%$ (BPS Jakarta, 2014). This should be a concern because the behavior and habits of the Indonesian people who often dump trash directly into rivers or into nature ultimately pollute the ecosystem (CNN Indonesia, 2018). The behavior of disposing of waste is an individual physical activity which is clearly seen as a habit formed by the environment (Tia et al., 2017), therefore it is necessary to raise awareness early on about caring for the environment in learning.

The application of teaching environmental education to students, can increase environmental awareness and bring positive attitude changes to students (Fua et al., 2018). Strategies undertaken by schools to make students care about the environment, in addition to integration through learning, also exemplary, habituation, and the message of protecting the environment. The results show that environmental care behavior is in the $50 \%$ category of very good, and $33 \%$ is 
good, the rest is sufficient, not good, and, bad (Adawiah, 2018). Environmental education taught through habituation has a direct influence, because the relationship between students and the environment can build values or behaviors of environmental values or attitudes that play a role in creating situations and conditions that support the growth of environmental care characters. Environmental education strategy with habituation is a social learning strategy that can be done as a solution to shape the character of students' environmental education.

The activity of habituation of lisambil is the learning of caring for the environment in a participatory way to foster an attitude of caring for the environment in order to shape the character of caring for the environment. According to Azhari et al., (2017), habituation activities are the same repetition activities, deliberately carried out repeatedly to link the stimulus to the response, so that it becomes very strong and not easily forgotten.

The main foundation in the lisambil process is the habit of taking trash continuously by students at school. According to the view of behavioristic learning theory changes in behavior as a result of the interaction between stimulus and response. The stimulus is in the form of habituation while the response is in the form of a caring attitude towards the environment. Behavior can be conditioned by using the habituation method where the more often the habituation (as a form of reinforcement), the stronger the behavior (Asri, 2005). Students have a tendency to adjust to the environment. In learning cognitive structures, environmental problems are real problems faced by students in school, solving them with habituation learning, so that the structure of environmental knowledge is a problem faced by students, and habituation as a stimulus and response arises in the form of behavior. According to Ansrori (2009), the formation of cognitive relationships with students' learning processes with lisambil habituation, forming behavior, so that mental to understand the environment will give birth to physical actions as a solution

The habit of lisambil is social learning or social cognitive in growing the character of caring for the environment, students receive information repeatedly, as a stimulus given to students. Information repeatedly is a revolutionary and adaptive strategy that will respond to environmental care behaviors. According to the research of Whallen et al., (2018) social learning is very dependent on the ability of each student to obtain relevant and accurate information from informants. Information knowledge is a very important signal in behavior change. The results of the research by Priyanto et al., (2013) by combining the concepts of behavioristic learning, constructivism, and social cognitive, in education, produce a level of environmental concern for students at the level, very high, high and moderate.

This program is an implementation of participatory environment-based activities, which is one of the standard components of Adiwiyata implemented by SMP Negeri 21 Pekanbaru, by developing cultural values and environmental care characters to realize Adiwiyata schools that care and are cultured in the 
environment. This participatory-based environmental activity standard implements planned environmental protection and management activities for school residents by implementing maintaining and maintaining buildings, school environments by school residents. Achievement of participatory activities is carried out through the implementation of the graduation program conducted by students at SMP Negeri 21 Pekanbaru. The implementation program and form of activities are in accordance with Adiwiyata's implementation standards, namely (1) Students carry out daily pickets, on a scheduled basis for effective learning every day. The habit of taking rubbish and putting it in the right place for the type of organic and inorganic waste and cleaning the room in the classroom and outside the classroom, caring for plants by watering it. This activity is supervised by every teacher who picks on a scheduled basis; (2) The habit of taking trash inside and outside the classroom before KBM starts after the first and second breaks. Habituation to see the garbage and take it, and put it in a place according to the type of organic and inorganic waste. This activity is carried out by all students in each class who are supervised by the subject teacher who will teach in the class; (3) Every Thursday the activity of "Thursday is clean the environment" (Kamberli). Students make a habit of seeing garbage and picking it up, then putting the garbage in the appropriate place for organic and inorganic waste. In addition, the recycle, reuse, replant and reduse activities are carried out with the homeroom teacher. (4) Retrieval habituation activities are carried out spontaneously, when students who are late coming to school, as punisments that violate the rules, the habituation of lisambil is applied to students to collect rubbish that is littered in the school yard and is placed according to the type of organic and inorganic waste. supervised by several picket teachers on a scheduled basis; (5) Scheduled habituation activities are scheduled to be carried out once a semester with the cleanest, most beautiful class competition with decorations made from recycled materials and good care of plants. Give rewards to classes that are judged to be appropriate according to the assessment format determined by the cleanliness, beauty and order assessment team. The selected class with the highest score will be given a prize that aims to motivate environmental care while providing cleaning equipment to support classroom hygiene.

Pekanbaru 21 Junior High School has implemented lisambil habituation, starting in 2015 until when the study was conducted (2018). Researchers still find rubbish scattered in the school environment, therefore a study was conducted aimed at evaluating the growth of students environmental care character, in the implementation of lisambil habituation. Growth of environmental care character in lisambil habituation, by measuring the actions and environmental hygiene of students in Lisambil habituation activities.

\section{Methodology}

The study was conducted at SMP Negeri 21 Pekanbaru located on Jalan Soekarno Hatta No. 639, Kelurahan Sidomulyo Timur, Marpoyan Damai Subdistrict, Riau Province. The study was conducted in the odd semester of 2018. Ex-postfacto research (sukardi, 2012) where data collection was carried out after the action, using 
survey methods. The study population was students of class VIII spread over 9 study groups with a total of 380 students. Sampling method used a random sampling technique that is a traditional random sampling technique such as taking lottery numbers in each class (Sukardi, 2012), with an error rate of 5\% so that a sample of 182 samples is obtained (Sugiyono, 2016). The independent variable in research was the habit of lisambil and the dependent variable was the growth of students environmental care character. The parameters in this study were the perceptions of teachers, principals and students. Growth of character care for the environment. The parameters of teacher and student perceptions with measurement aspects, namely, the perception of habituation of lisambil on class picket activities, Camberli, before KBM, punishment and reward. The parameters of the principal perception by measuring the planning, implementation and evaluation of the implementation of the graduation program. The parameters for the growth of the character of caring for the environment of students by measuring namely, the actions of growing the character of caring for the environment with aspects of habituation of class picket activities, Camberism and punisment and measuring environmental cleanliness in the classroom and outside the classroom with aspects of hygiene class picket activities, Camberli, and before KBM. Data collection techniques in research was by spreading questionnaire perception of teachers, principals, and students.

\section{Results and Discussion}

The results of measurements of teacher perceptions in the implementation of the graduation program at SMP Negeri 21 Pekanbaru are presented in Table 1

Table 1. Teachers' perception of the implementation of the take-up program in SMP Negeri 21 Pekanbaru

\begin{tabular}{llll}
\hline Aspect & Average score & Measurement (\%) & Category \\
\hline Class picket & 4,52 & 90 & Good \\
Before KBM & 4,65 & 93 & Good \\
Kamberli & 4,40 & 87 & Good \\
Punisment & 4,24 & 85 & Good \\
Reward & 4,40 & 88 & Good \\
\hline Average & 4,44 & 88 & Good \\
\hline
\end{tabular}

Table 1 states that the teacher perception of the implementation of the graduation program is of good value $(88 \%)$ with a mean score of 4.44 , meaning that the teacher has the perception that it is important to implement the retrieval program because the retrieval program is a program that can foster environmental character. The lisambil program is one of the Adiwiyata programs in SMP Negeri 21 Pekanbaru. Therefore the teacher feels responsible for the implementation of part of the Adiwiyata program. This is in accordance with the opinion of Septi \& Kokom (2017), the teacher really understands the Adiwiyata program because this program can increase environmental awareness, because the environmentally oriented Adiwiayata program teaches students to care for the environment around the school and outside the school environment. One of the revitalization programs in Adiwiyata can be seen in Figure 1. 


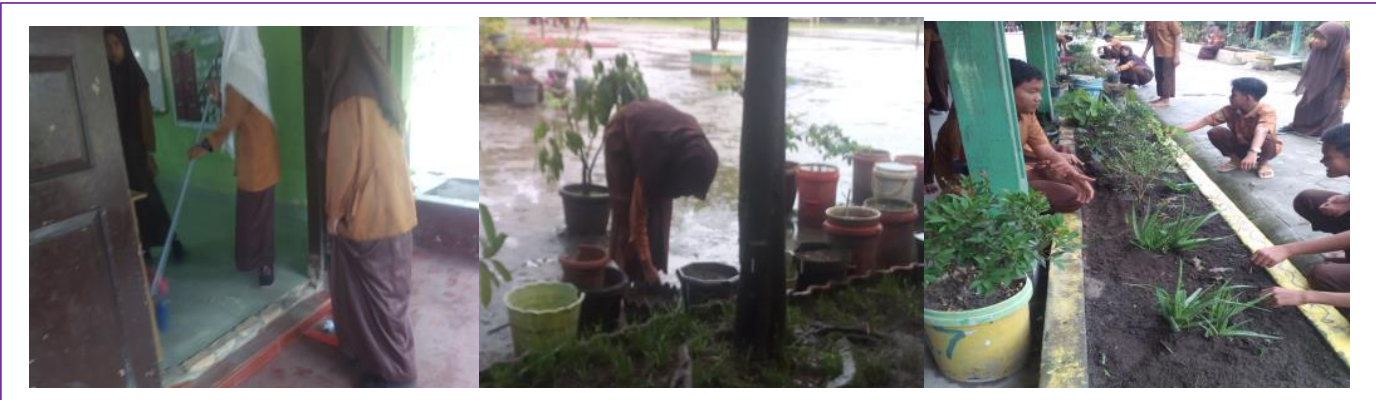

Figure 1. Lisambil Kamberli habituation activities

The results of measurements of school principals' perceptions of the implementation of the graduation program at SMP Negeri 21 Pekanbaru are presented in Table 2.

Table 2. Perceptions of school principals on the implementation of the graduation program at SMP Negeri 21 Pekanbaru

\begin{tabular}{llll}
\hline Aspect & Average score & Measurement (\%) & Category \\
\hline Planning & 6,40 & 91 & Good \\
Implementation & 5.00 & 100 & Good \\
Evaluation & 4,67 & 93 & Good \\
\hline Average & 4,69 & 94 & Good \\
\hline
\end{tabular}

Table 2 states that the perception of school principals related to aspects of implementing the implementation of the lisambil program is good (100\%) with an average score of 5.00. All aspects of the school principal's perception in the good category, stated that the school principal strongly supports the implementation of the lisambil program.

The results of measurements of students perceptions in the implementation of the graduation program at SMP Negeri 21 Pekanbaru are presented in Table 3.

Table 3. Students' perceptions of the implementation of the graduation program at SMP Negeri 21 Pekanbaru

\begin{tabular}{llll}
\hline Aspect & Average score & Measurement (\%) & Category \\
\hline Class picket & 5,35 & 77 & Good \\
Before KBM & 1,90 & 63 & Enough \\
Kamberli & 4,60 & 77 & Good \\
Punisment & 3,80 & 76 & Good \\
Reward & 5,35 & 92 & Good \\
\hline Average & 4,24 & 79 & Good \\
\hline
\end{tabular}

Table 3 states that students perceptions of aspects of class picket, Camberli, punishment and reward are with good categories. In the aspects before KBM with enough categories. The difference in students perceptions on aspects before KBM is due to the lack of motivation given by the teacher in the habit of graduation by getting students to see the garbage and pick it up and place it in a place that is 
suitable for the type of organic and inorganic waste at the time before the learning activities begin after a break.

According to Bahij \& Santi (2017), differences in perceptions among students are due to different understanding of the Adiwiyata program. Besides the religious values and age of students also affect the development of student character (Zulkifli, 2019). Furthermore Sumarlin et al., (2013) states, knowledge and socioeconomic influence student perceptions, for that the role of the teacher to internalize the value of environmental care is needed. Students' perceptions of aspects taken before the KBM with sufficient categories, this happens because of the lack of teacher responsibility in supervising and providing motivation in the form of direction to students. The teacher is less active in motivating in the habit of graduation before KBM. Principals are less concerned with the implementation of lisambil habituation activities before KBM, finally teachers are not motivated to be active in lisambil habituation activities before KBM. Teacher boredom is also a cause of students' perceptions with sufficient categories. The school principal should evaluate the implementation of the implementation of the lisambil program periodically, in order to find out the weaknesses and shortcomings of the lisambil habituation activity in the habituation aspect before $\mathrm{KBM}$. therefore the headmaster can provide activities that can motivate teachers to be active in the habit of lisambil activities such as holding workshops processing used goods into goods that are useful and economically valuable. In addition by holding comparative study activities to adiwiyata school on an independent level. The activities carried out are expected to help provide stimulus to teachers and students so that the habituation of lisambil gets a good response from students.

According to Retno (2012), states that school leaders must move teachers and students to care for the environment through environmental care programs. The teacher becomes a motivator and inspiration in learning. Habituation is part of learning, so students' perceptions become good in the habituation program. Furthermore, school principals can carry out activities that support the students 'awareness of the environment, such as holding a competition to make slogans accompanied by pictures so that the process of environmental awareness can change students' perceptions of the environment. In line with the opinion of Syaufina et al., (2016), students' perceptions influence behavior, so it needs to be given environmental awareness.

Activities that can be carried out to influence environmental awareness behavior such as holding a waste management competition are of economic value, for example making souvenirs from boxes and plastic beverage packaging. In addition to influencing behavior so that environmental love requires wise sentences in protecting the environment, in the form of posters posted on the walls of classrooms and in places that are often forgotten from the teacher's watch. Therefore the principal needs to increase his competence to develop activities that support the liisambil program. 
Examples must be demonstrated, such as during the Kamberli activities, the principal and teachers must join together with students to carry out activities that care about the environment. Furthermore, Amirul (2014) states that the role models of school principals and teachers can also be a strategy in the implementation of environmental awareness programs, so students can have the same perception as school principals and teachers.

The results of observing the students environmental care actions in the habituation of students of SMP Negeri 21 Pekanbaru with three aspects of parameters related to the habits of student practice are presented in table 4 .

Table 4. Measures to Grow Students' Environmental Care Characters in Implementing the Take-Up Program in SMP Negeri 21 Pekanbaru

\begin{tabular}{lll}
\hline Aspect & Actions (\%) & Category \\
\hline Picket implementation & 56 & Enough \\
The implementation of Kamberli & 76 & Good \\
Execution of punishment & 75 & Good \\
\hline Average & 69 & Good \\
\hline
\end{tabular}

Table 4 shows that the growth of environmentally friendly character in the aspect of picket implementation is 56\% enough category, the aspect of implementation of the recurrence and punishment is $75 \%, 75 \%$ good category. The aspects of picket implementation get enough categories, there are differences in the character growth actions on the aspects of picket implementation. This shows that the growth of character care about the environment of individual students is still low. The low growth of character of environmental care is caused by the lack of supervision and evaluation by the teacher in class picket activities, so that there are those who carry out their duties and responsibilities when picket picks up picks up trash and places rubbish according to the type of organic and inorganic waste and activities caring for plants by watering plants. Supervision and evaluation are part of the learning process that students need in implementing class pickets so students are aware of their responsibilities. The development of this environmentally-aware character takes time, it must be nurtured continuously so that the character flourishes in each individual student. The aspects of class picking are part of the individual learning process for students in habituation of lisambil so that students care about the environment, therefore teachers must provide continuous guidance in the actions of pickets in class by monitoring and evaluating so that the actions of habituation can be increased.

According to Retno (2012), stating that character education is an effort to guide student behavior in order to love and do good the focus on ethical goals through the process of deepening appreciation and habituation. Reinforced by Iqbal et al., (2014), character building requires exemplary teachers in loving and doing good to the environment.

The punishment aspect also determines the growth of environmental care character in the implementation of the license program, because punishment can motivate, according to the results of the measurement aspect of punishment 
received a good category, According to Umi et al., (2018), states that in the implementation of the Adiwiyata program, reward and punishment an alternative motivate students to maintain the environment character.

The results of observations of students 'environmental cleanliness in the habit of graduation in SMP Negeri 21 Pekanbaru completed the graduation activities in every aspect obtained the results of students' environmental cleanliness are presented in Table 5.

Table 5. Cleanliness after the action of growing environmental care characters in the implementation of the graduation program at SMP Negeri 21 Pekanbaru

\begin{tabular}{lllll}
\hline \multirow{2}{*}{ Aspect } & \multicolumn{2}{c}{ In the classroom } & \multicolumn{2}{c}{ Outside the classroom } \\
\cline { 2 - 5 } & Cleanliness (\%) & Category & Cleanliness (\%) & Category \\
\cline { 2 - 5 } Cleanliness Picket & 71,1 & Good & 22,2 & Less \\
Cleanliness Kamberli & 100 & Good & 44 & Less \\
Cleanliness before KBM & 60 & Enough & 20 & Less \\
\hline Average & 77 & Good & 28,73 & Less \\
\hline
\end{tabular}

Table 5 states that cleanliness in the classroom and outside the classroom after the action of the growth of character care for the environment there are differences, in class $71.1 \%$ good category while outside the class $22.2 \%$ the category is less. The hygiene aspect after Camberli also experienced differences in the $100 \%$ class in the good category and outside the class in $44 \%$ the less category. The cleanliness aspect before $\mathrm{KBM}$ in the class is $60 \%$ with enough category, while the cleanliness outside the class is $20 \%$ with less category.

Cleanliness in the classroom is seen from the aspect before KBM with sufficient category, because teacher supervision is not optimal when in the classroom. The teacher feels burdened to supervise habituation activities, because those who carry out habituation activities before KBM are the same teacher every day, related to the teaching schedule at the time. The teacher feels bored to remind students to take trash and place it according to the type of organic and inorganic waste.

The cleanliness aspects outside the classroom after the action of growing the character of environmental care for all aspects measured are class picket hygiene, Camberli, and before KBM gets a category score of less. The reason is because the teacher's concern in supervision and evaluation of all aspects of lisambil habituation activities is still lacking. Improving students' concern for the environment in the implementation of the graduation program requires the role of the teacher. The teacher must be active in overseeing all activities. Also in line with opinions (Marina, et.al, 2019) teachers must be able to provide motivation so that students become disciplined. This is related to the teacher's ability to direct students to better understand an activity process.

The cleanliness aspect outside the classroom on picket activities must be monitored during the activity and after the picket is done a hygiene evaluation, if there is still garbage scattered, then students are told to repeat seeing the garbage and pick it up and place it according to the type of organic and inorganic waste. If 
the monitoring and evaluation activities are carried out by the teacher continuously, it will have an impact on student behavior, so students care about maintaining environmental cleanliness. According to Fathurahman, (2017), habituation of environmental care behaviors will shape the character of caring for students' environment, and students will have the habit of protecting, caring for, and preserving the environment.

The cleanliness aspect outside the classroom in the Kamberli activities also lacks supervision from the teacher. In the Kamberli activity the teacher only entrusts to the class leader to supervise students in this activity. The teacher should be directly involved, because the teacher's participation in the activities can motivate students to carry out environmental care activities to pick up trash and put it according to its type, then the teacher evaluates students in placing waste according to the type of organic and inorganic waste. If the waste placement is not appropriate, the teacher gives an understanding of organic and inorganic waste knowledge. so that students' concern for the environment can be increased. Furthermore, the teacher invites students to use garbage by processing it into items that can be used and are economically valuable. Waste management by recycle, reduce and provide reuse understanding. Recycle processing, for example, uses a plastic beverage packaging bottle used as a pot to grow plants. For organic waste that has been collected such as leaves from plants can be processed into compost. The teacher also reminds students to be able to use items that can minimize the amount of waste, for example bringing drink bottles from home, students are banned from using paper towels, using cloth rags that can be washed and reused repeatedly.

Increased awareness of the environment outside the classroom can also be done through a learning process designed by teachers in accordance with the concept of guided environmental learning such as learning related to environmental pollution. According to Ratnasari, et al., (2015) states that learning that is well designed by teachers can increase students' environmental awareness. Learning can be done in a guided manner such as the case of environmental pollution. Furthermore Maisyarotul et al., (2014) stated, if students apply the knowledge gained in learning, the attitude of caring for the environment will be good. In line with that the science process skills in learning can contribute to student attitudes (Zulirfan, et.al, 2018). In addition, the involvement of all stakeholders in the implementation of the Adiwiyata program can increase environmental awareness of students (Gina, 2016).

\section{Conclusion}

The perception of the majority of teachers is good, the principal is good and students' perceptions are also good towards the implementation of the habit of graduation in SMP Negeri 21 Pekanbaru. Students' perceptions on the aspect of habituation before KBM began in the sufficient category, due to lack of motivation and apperception from teachers and principals. 
The act of growing students' environmental care character in the habit of graduation when viewed from all aspects of good value. The aspect of customizing action while picking activities gets sufficient marks, due to lack of supervision and evaluation from the teacher.

The cleanliness of the environment after the act of growing the character of caring for the environment in all aspects of cleanliness in the classroom is good. In the aspect of habituation of lisambil before KBM gets sufficient grades, due to the teacher being less active in habituation of lisambil, not providing a stimulus to students, then students' concern for environmental cleanliness becomes less.

\section{Acknowledgement}

Thank you to researchers who have published their research so that I can use the results of research as a reference in writing the results of this research. Hopefully this article will be useful for future researchers

\section{References}

Adawiah, R. (2018). Instilling the Environmental Care Characters to the Elementary Schools Located an the Rivers Banks. Journal of Wetlands Environmental Management 6 (1), 84-92.

Agung,L. (2011). Character Education Integration In Social Studies Learning. International Journal Of History

Bandura, B.A., Ross. D., Ross, S. A., Hart,K.E., \& Kritsonis,W.A (2006). Critical Analysis of an Original Writing on Social Learning Theory: Imitation of Film-Mediated Aggressive Models. National Forum Applied Educational Research Journal 19 ( 3), 1-7

Ansrori, M. (2009). Psikologi Pembelajaran. Wacana Prima, Jakarta

Asri. B. (2005). Belajar dan Pembelajaran. PT. Rineka Cipta, Jakarta

Azhari,R., Chusniatun, \& Zaenal, A. (2017). Metode Pembiasaan Sebagai Upaya Internalisasi Nilai-Nilai Ajaran Islam Di SMP Muhammadiyah 5 Surakarta Tahun Pelajaran 2015/2016 thesis, Universitas Muhammadiyah Surakarta.

Bahij, A.A., \& Santi, A.U.P. (2017). Persepsi Siswa Sekolah Dasar Tentang Lingkungan Hidup. Jurnal Holistica 1 (1), 1-7

Bandura, B.A., Ross. D., Ross, S. A., Hart,K.E., \& Kritsonis,W.A (2006). Critical Analysis of an Original Writing on Social Learning Theory: Imitation of Film-Mediated Aggressive Models. National Forum Applied Educational Research Journal 19 ( 3) ,1-7

BPS Jakarta, (2014). Indikator Kepedulian Lingkungan Hidup. (Hasil Survey Sosial ekonomi Nasional 2014, Modul Ketahanan Sosial ). BPS Indonesia, Jakarta

Chusnani, D. (2013). Pendidikan Karakter Melalui Sains. Jurnal Kebijakan dan Pengembangan 1 (1), 9-13

CNN Indonesia, (2018). Riset: 24 Persen Sampah Di Indonesia Masih Tak Terkelola. https://www.cnnindonesia.com. Diakses 14 Oktober 2018 
Fua, J. La, Nurlila,R.U., Ratna \& Wekke, I.S., (2018). Strategy of Islamic Education in Developing Character Building of Environmental Students in Indonesia. IOP Conf. Series: Earth and Environmental Science (175) 012149

Irene, S., \& Dwinigrum, A. (2017). Nation's Character Education Based on the $\begin{array}{llll}\text { Social Capital Theory } 9 & \text { (12), }\end{array}$ http://doi.org/10.5539/ass.v9n12p144

Iswardi, R, D. \& Utomo, S. W. (2017) . Evaluasi Penerapan Program Adiwiyata Untuk menbentuk Perilaku Peduli Lingkungan di Kalangan Siswa. Jurnal Ilmu Lingkungan progranm Studi Sekolah Pascasarjana UNDIP 15 (1), 35-41. http.org/10.14710/jil.15.1.35-41

Malik. M., Rahim. R, Bactiar.N, \& Fahmy.R., (2015). Measuring student perception to personal characters building in education:An Indonesia Case In Implemetating new curiculum In High School. Science Direct Procedia - Social and Behavioral Sciences (211), 851 - 858. http://doi.org/10.1016/j.sbspro.2015.11.112

Maisyarotul. H, Rachmadiarti, \& Muji S.P., (2014). Penguasaan Konsep Lingkungan Dan Sikap Kepedulian Lingkungan Siswa SMA Adiwiyata Mandiri Kabupaten Mojokerto. Jurnal BioEdu Berkala Ilmiah Pendidikan Biologi 3 (3), 479-484

Kementrian Pendidikan Nasional [Kemendiknas], (2010). Pengembangan Pendidikan Budaya dan Karakter Bangsa. Badan Penelitan dan Pengembangan Pusat Kurikulum, Jakarta

Priyanto, Y., Djati, M.S., \& Fanani, Z, (2013). Pendidikan Berpresfektif Lingkungan menuju Pembanguan Berkelanjutan Environmental Perspective Education Towards Sustainable. Jurnal Program studi kajian lingkungan dan pembangunan, program parcasarjana universitas brawijaya 16 (1), 41-51

Ratnasari, Endang, A \& Djohar, (2015). Penerapan Model Pembelajaran Inkuiri Terbimbing (Quided Innqury) Untuk Meningkatkan Sikap Peduli Terhadap Lingkunga Pada Konsep Pencemaran Lingkungan Di Kelas VII SMP Negeri Sumber, Jurnal Scientiae Educatia 3 (2), 1-9

Retno, L. (2012). Pendidikan Karakter Dalam Metode Aktif, Inovatif \& Kreatif. Penerbit Erlangga, Jakarta

Rokhman,F., Hum, M \& Syifudin,A. (2014). Character Education For Golden Generation 2045 (National Character Building for Indonesian Golden Years). Procedia - Social and Behavioral Sciences 141, 1161-1165. http://doi.org/10.1016/j.sbspro .2014.05. 197

Sofian, A. (2018).Internalization of character Education in the SMPIT As-syifa Boarding School. Jurnal Pendidikan Sains Sosial dan Kemanusian 11 (1), 47-62

Tia, A., Hemy. H. A., \& Neka.E, (2017). Perbedaan Perilaku Membuang Sampah Pada Siswa Antara Sebelum Dan Sesudah Diberikan Live And Simbolik.Jurnal Ecopsy, 4 ( 2), 96-102.

Umi, F., Sri, N., \& Lisdiana. (2018). The Adiwiyata School"s Role in the Development of Character Caring for the Environment (A Case Study at the Junior High School 6 Tuban) Journal of Innovative Science education $7(1), 54-62$ 
Utomo, Y., \& Juul, E. (2017). Habituation Model Of Implementing Environmental Education In Elementary School. Jurnal Pendidikan Indonesia 6 (2), 206-212. http://doi.org/10.15294/jpoo.v6i2.10200

Whallen, A.,Griffiths, T.L., \& Buchsbaum, D. (2018). Sensitivity to Shared Information in Social Learning. Cognitive Science Multydicipline Journal (42,) 168-187.http://doi.1111/cogs. 12485

Zainal.A., \& Sujak, (2011). Panduan \& Aplikasi Pendidikan Karakter. Yrama Widya, Bandung

How to cite this article:

Deswati, Suwondo, \& Firdaus LN. (2020). Student Growth of Care Characters of Students 'Environment in the Lisambil Discussion in Smp Negeri 21 Pekanbaru. Journal of Educational Sciences, 4(1), 93-105. 